\title{
Kinetics and Mechanism of Oxidative Dehydrogenation of Propane on Vanadium, Molybdenum, and Tungsten Oxides
}

\author{
Kaidong Chen, Alexis T. Bell,* and Enrique Iglesia* \\ Chemical and Materials Sciences Divisions, Lawrence Berkeley National Laboratory, and Department of \\ Chemical Engineering, University of California, Berkeley, California 94720-1462 \\ Received: September 21, 1999; In Final Form: November 24, 1999
}

\begin{abstract}
The effect of cation identity on oxidative dehydrogenation (ODH) pathways was examined using two-dimensional $\mathrm{VO}_{x}, \mathrm{MoO}_{x}$, and $\mathrm{WO}_{x}$ structures supported on $\mathrm{ZrO}_{2}$. The similar kinetic rate expressions obtained on $\mathrm{MoO}_{x}$ and $\mathrm{VO}_{x}$ catalysts confirmed that oxidative dehydrogenation of propane occurs via similar pathways, which involve rate-determining $\mathrm{C}-\mathrm{H}$ bond activation steps using lattice oxygen atoms. The activation energies for propane dehydrogenation and for propene combustion increase in the sequence $\mathrm{VO}_{x} / \mathrm{ZrO}_{2}<$ $\mathrm{MoO}_{x} / \mathrm{ZrO} \mathrm{W}_{2}<\mathrm{WO}_{x} / \mathrm{ZrO}_{2}$; the corresponding reaction rates decrease in this sequence, suggesting that turnover rates reflect $\mathrm{C}-\mathrm{H}$ bond cleavage activation energies, which are in turn influenced by the reducibility of these metal oxides. Propane ODH activation energies are higher than for propene combustion. This leads to an increase in maximum alkene yields and in the ratio of rate constants for propane ODH and propene combustion as temperature increases. This difference in activation energy $(48-61 \mathrm{~kJ} / \mathrm{mol})$ between propane $\mathrm{ODH}$ and propene combustion is larger than between bond dissociation enthalpies for the weakest $\mathrm{C}-\mathrm{H}$ bond in propane and propene $(40 \mathrm{~kJ} / \mathrm{mol})$ and it increases in the sequence $\mathrm{VO}_{x} / \mathrm{ZrO}_{2}<\mathrm{MoO}_{x} / \mathrm{ZrO}_{2}<\mathrm{WO}_{x} / \mathrm{ZrO}_{2}$. These results suggest that relative propane $\mathrm{ODH}$ and propene combustion rates depend not only on $\mathrm{C}-\mathrm{H}$ bond energy differences but also on the adsorption enthalpies for propene and propane, which reflect the Lewis acidity of cations involved in $\pi$ bonding of alkenes on oxide surfaces. The observed difference in activation energies between propane $\mathrm{ODH}$ and propene combustion increases as the Lewis acidity of the cations increases $\left(\mathrm{V}^{5+}\right.$ $\left.<\mathrm{Mo}^{6+}<\mathrm{W}^{6+}\right)$.
\end{abstract}

\section{Introduction}

In spite of its significant economic potential as an alternate route to alkenes ${ }^{1-5}$ and in spite of extensive scientific studies, ${ }^{1-22}$ the oxidative dehydrogenation (ODH) of alkanes to alkenes is not currently practiced because the secondary combustion of primary alkene products limits alkene yields to about $30 \%$ for propane and higher alkanes. ${ }^{3}$ Alkene selectivities decrease markedly as conversion increases. ${ }^{2,3}$ One important reason for these yield limitations is the typically higher energies of the $\mathrm{C}-\mathrm{H}$ bonds in alkane reactants compared with those in the desired alkene products, ${ }^{23}$ which lead to rapid alkene combustion at the temperatures required for $\mathrm{C}-\mathrm{H}$ bond activation in alkanes. A recent literature survey of product yields in oxidation reactions $^{23}$ suggested that low yields are obtained when the energy of the weakest bond in the products is $30-40 \mathrm{~kJ} / \mathrm{mol}$ lower than that of the weakest bond in the reactants.

The oxidation of light alkanes to alkenes occurs via parallel and sequential oxidation steps (Scheme 1). ${ }^{1}$ Alkenes are primary $\mathrm{ODH}$ products while $\mathrm{CO}$ and $\mathrm{CO}_{2}\left(\mathrm{CO}_{x}\right)$ can form via either secondary combustion of alkenes or direct combustion of alkanes. Selective poisoning of sites responsible for direct combustion of alkanes using $\mathrm{SiO}_{x}$ has been reported. ${ }^{24}$ The activation of $\mathrm{C}-\mathrm{H}$ bonds in alkane $\mathrm{ODH}$ reactions, however, appears to require the same sites as the $\mathrm{C}-\mathrm{H}$ bond activation steps involved in the combustion of alkenes, ${ }^{25,26}$ making

* Authors to whom correspondence should be addressed. E-mail: iglesia@cchem.berkeley.edu; bell@cchem.berkeley.edu.
SCHEME 1: Reaction Network in Oxidative
Dehydrogenation of Alkane Reactions

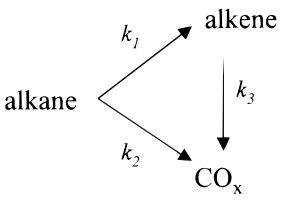

selective poisoning strategies ineffective in improving alkene yields. On $\mathrm{VO}_{x}$-based catalysts, the evolution of oxide structures from monovanadate to polyvanadate species as $\mathrm{VO}_{x}$ surface density increases leads to a similar increase in ODH and propene combustion rates, apparently because similar sites are required for the two reactions. ${ }^{26}$ Propane combustion rates, however, are less affected by $\mathrm{VO}_{x}$ surface density, which leads to a decrease in $k_{2} / k_{1}$ ratios as surface density increases. ${ }^{25,26}$ Initial selectivities greater than $90 \%$ can be achieved for many ODH reactions. ${ }^{2,3}$ The $k_{3} / k_{1}$ (propene secondary combustion/propane primary dehydrogenation) ratio, which causes the yield losses observed as conversion increases, is large $(5-40)$ on $\mathrm{VO}_{x}$-based catalysts. ${ }^{25,26}$ The greater reactivity of propene arises in part because the weakest $\mathrm{C}-\mathrm{H}$ bond in propane (at the methylene group) is significantly stronger than the allylic $\mathrm{C}-\mathrm{H}$ bond in propene. ${ }^{23}$ If the relative $\mathrm{C}-\mathrm{H}$ bond dissociation enthalpies were the only factor responsible for the $k_{3} / k_{1}$ ratio, this ratio would not depend on the chemical identity or the local structure of the active oxide. The differences observed among $\mathrm{VO}_{x}, \mathrm{MoO}_{x}, \mathrm{WO}_{x}$ and other oxides suggest that other factors, such as differences in 
TABLE 1: Structure of $\mathrm{MO}_{x} / \mathrm{ZrO}_{2}(\mathrm{M}=\mathrm{V}$, Mo, W) Catalysts

\begin{tabular}{llll}
\hline catalyst & $10 \mathrm{wt} \% \mathrm{VO}_{x} / \mathrm{ZrO}_{2}$ & $11 \mathrm{wt} \% \mathrm{MoO}_{x} / \mathrm{ZrO}_{2}$ & $20 \mathrm{wt} \% \mathrm{WO}_{x} / \mathrm{ZrO}_{2}$ \\
treatment temp $(\mathrm{K})$ & 773 & 773 & 873 \\
$\mathrm{BET}$ surface area $\left(\mathrm{m}^{2} / \mathrm{g}\right)$ & 170 & 133 & 124 \\
$\mathrm{MO}_{x}$ surface density $\left(\mathrm{M}\right.$ atom $\left./ \mathrm{nm}^{2}\right)$ & 3.9 & 3.5 & 4.2 \\
predominant $\mathrm{MO}_{x}$ structure & polyvanadate & polymolybdate & polytungstate
\end{tabular}

${ }^{a} \mathrm{M}=\mathrm{V}$, Mo, W. ${ }^{b}$ Inferred from Raman and UV-visible spectroscopy data.

adsorption enthalpy or entropy between alkanes and alkenes, and therefore the acid-base properties of active oxides and of supports, may also influence $k_{3} / k_{1}$ ratios and alkene yields.

$\mathrm{VO}_{x}$-based materials are among the most active and selective oxidative dehydrogenation catalysts. ${ }^{1-5}$ Polyvanadate structures on $\mathrm{ZrO}_{2}$ lead to reducible and accessible $\mathrm{VO}_{x}$ domains and to more active catalysts than $\mathrm{VO}_{x}$ dispersed on other supports. ${ }^{26}$ $\mathrm{ZrO}_{2}$-supported $\mathrm{MoO}_{x}$ species have also been examined as alkane ODH catalysts; ${ }^{18,27,28} \mathrm{ODH}$ rates tend to be lower on $\mathrm{MoO}_{x}$ than on $\mathrm{VO}_{x}$ domains, but $\mathrm{MoO}_{x}$-based catalysts retain their dispersion and structure at significantly higher temperatures than $\mathrm{VO}_{x}$-based catalysts. Catalysts based on $\mathrm{WO}_{x}$ domains are seldom used because of their low ODH activity. This study addresses the chemical and structural basis for the observed differences in $\mathrm{ODH}$ rates and in rate constants for individual reaction steps on $\mathrm{VO}_{x}, \mathrm{MoO}_{x}$, and $\mathrm{WO}_{x}$ catalysts. Detailed ODH kinetics, including activation energies and entropies for primary dehydrogenation and secondary combustion, are reported. They are used to identify relevant factors influencing $k_{3} / k_{1}$ and $k_{2} / k_{1}$ ratios for reactions of propane and propene on these catalysts.

\section{Experimental Methods}

$\mathrm{V}_{2} \mathrm{O}_{5} / \mathrm{ZrO}_{2}\left(10\right.$ wt $\left.\% \mathrm{~V}_{2} \mathrm{O}_{5}\right), \mathrm{MoO}_{3} / \mathrm{ZrO}_{2}\left(11\right.$ wt $\left.\% \mathrm{MoO}_{3}\right)$, and $\mathrm{WO}_{3} / \mathrm{ZrO}_{2}\left(20 \mathrm{wt} \% \mathrm{WO}_{3}\right)$ catalysts were prepared by incipient wetness impregnation of $\mathrm{ZrO}_{x}(\mathrm{OH})_{4-2 x}$ with solutions of $\mathrm{NH}_{4} \mathrm{VO}_{3},{ }^{25}\left(\mathrm{NH}_{4}\right)_{2} \mathrm{Mo}_{2} \mathrm{O}_{7},{ }^{27}$ and $\left(\mathrm{NH}_{4}\right)_{6} \mathrm{H}_{2} \mathrm{~W}_{12} \mathrm{O}_{40},{ }^{29,30}$ respectively. Surface areas were measured by $\mathrm{N}_{2}$ physisorption at its boiling point using a Quantasorb surface area analyzer (Quantachrome Corp.) and BET analysis methods.

Catalytic measurements were carried out in a packed-bed quartz microreactor with plug-flow hydrodynamics ${ }^{25}$ using $0.03-0.3 \mathrm{~g}$ catalyst samples. Quartz powder was used to dilute the bed and to minimize temperature gradients. Propane (Airgas, 99.9\%) and $\mathrm{O}_{2}$ (Airgas, 99.999\%) were used as reactants and He (Airgas, 99.999\%) was used as an inert diluent. Water was introduced into $\mathrm{C}_{3} \mathrm{H}_{8}-\mathrm{O}_{2}$ reactant streams by flowing a $20 \%$ $\mathrm{H}_{2} /$ Ar mixture through a $\mathrm{CuO}$ bed $(0.5 \mathrm{~m}$ long, $150 \mathrm{~g}$ of $\mathrm{CuO})$ held at $623 \mathrm{~K}$. Water was formed by $\mathrm{CuO}$ reduction to $\mathrm{Cu}$ metal. All transfer lines beyond the point of water introduction were kept above $393 \mathrm{~K}$ in order to prevent condensation. Reactants and products were analyzed with a Hewlett-Packard 6890 gas chromatograph using analysis procedures described elsewhere. ${ }^{25,26} \mathrm{C}_{3} \mathrm{H}_{8}$ and $\mathrm{O}_{2}$ conversions were varied by changing reactant flow rates $\left(50-200 \mathrm{~cm}^{3} / \mathrm{min}\right)$; they were kept below $2 \%$ and $20 \%$, respectively. Reaction rates and selectivities were extrapolated to zero residence time in order to determine initial reaction rates and selectivities. First-order rate constants for alkane $\mathrm{ODH}\left(k_{1}\right)$, primary alkane combustion $\left(k_{2}\right)$, and secondary combustion of alkenes $\left(k_{3}\right)$ were obtained from bed residence time effects on product distributions using previously described procedures. $^{25}$

\section{Results and Discussion}

Mechanism of Propane Oxidative Dehydrogenation. The BET surface area and the $\mathrm{MO}_{x}$ surface density for the catalysts

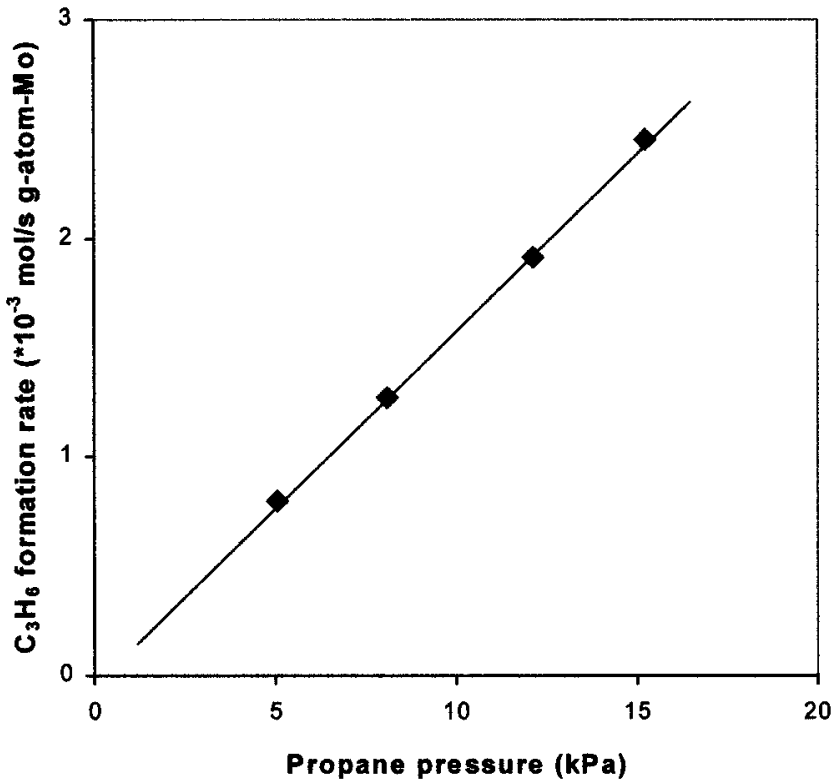

Figure 1. Effect of $\mathrm{C}_{3} \mathrm{H}_{8}$ pressure on $\mathrm{C}_{3} \mathrm{H}_{6}$ formation rate on $11 \mathrm{wt} \%$ $\mathrm{MoO}_{x} / \mathrm{ZrO}_{2}(703 \mathrm{~K}, 1.3 \mathrm{kPa} \mathrm{O}$, balance $\mathrm{He})$.

used in this study are shown in Table 1. All three samples were also characterized by X-ray diffraction and by X-ray absorption, Raman, and UV-visible spectroscopies. ${ }^{25-27,29,30}$ These methods were used to establish that the dispersed oxide species present in these samples were two-dimensional oligomers. Such oligomeric structures minimize the number of $\mathrm{M}-\mathrm{O}-\mathrm{Zr}$ linkages accessible to gas phase reactants and $\mathrm{M}-\mathrm{O}-\mathrm{Zr}$ linkages appear to be active for undesired propane combustion reactions. ${ }^{25,27}$

The kinetics and reaction pathways for propane $\mathrm{ODH}$ on $\mathrm{VO}_{x^{-}}$ based catalysts have been described in detail previously. ${ }^{31}$ The $\mathrm{ODH}$ rate is proportional to $\mathrm{C}_{3} \mathrm{H}_{8}$ partial pressures and independent of $\mathrm{O}_{2}$ partial pressures when $\mathrm{H}_{2} \mathrm{O}$ partial pressures are low; the rates acquire a more complex dependence on $\mathrm{C}_{3} \mathrm{H}_{8}$ and $\mathrm{O}_{2}$ pressures when $\mathrm{H}_{2} \mathrm{O}$ is present at higher concentrations. Similar kinetic dependencies were observed on $\mathrm{MoO}_{x} / \mathrm{ZrO}_{2}$. Figure 1 shows initial propene formation rates for $\mathrm{MoO}_{x} / \mathrm{ZrO}_{2}$ as a function of propane partial pressure at $1.3 \mathrm{kPa}$ of $\mathrm{O}_{2}$ without added $\mathrm{H}_{2} \mathrm{O}$. The propene formation rate increases linearly with increasing propane partial pressure, in agreement with previous reports. ${ }^{31-34}$ Propane $\mathrm{ODH}$ rates do not depend on $\mathrm{O}_{2}$ partial pressures when $\mathrm{H}_{2} \mathrm{O}$ is not added (Figure 2), in agreement with previous reports. ${ }^{31-33}$ The effect of $\mathrm{H}_{2} \mathrm{O}$ partial pressure on propane $\mathrm{ODH}$ rates is shown in Figure 3 at $8.1 \mathrm{kPa}$ of $\mathrm{C}_{3} \mathrm{H}_{8}$ and $1.3 \mathrm{kPa}$ of $\mathrm{O}_{2}$. Water inhibits propane $\mathrm{ODH}$ on $\mathrm{MoO}_{x}-$ $\mathrm{ZrO}_{2}$ catalysts in a manner similar to that reported on $\mathrm{VO}_{x}-$ $\mathrm{ZrO}_{2}{ }^{31}$ and $\mathrm{VO}_{x}-\mathrm{Al}_{2} \mathrm{O}_{3}{ }^{34}$ catalysts. This resemblance in the $\mathrm{ODH}$ kinetics on $\mathrm{MoO}_{x}-\mathrm{ZrO}_{2}$ and $\mathrm{VO}_{x}-\mathrm{ZrO}_{2}$ and complementary isotopic tracer studies of the reaction steps suggest that the elementary steps involved in alkane ODH reactions are also similar on $\mathrm{MoO}_{x}$ and $\mathrm{VO}_{x}$ catalysts. Detailed kinetics and isotopic tracer studies ${ }^{31}$ have shown that propane ODH occurs on $\mathrm{VO}_{x}$ domains via a Mars-van Krevelen redox mechanism 


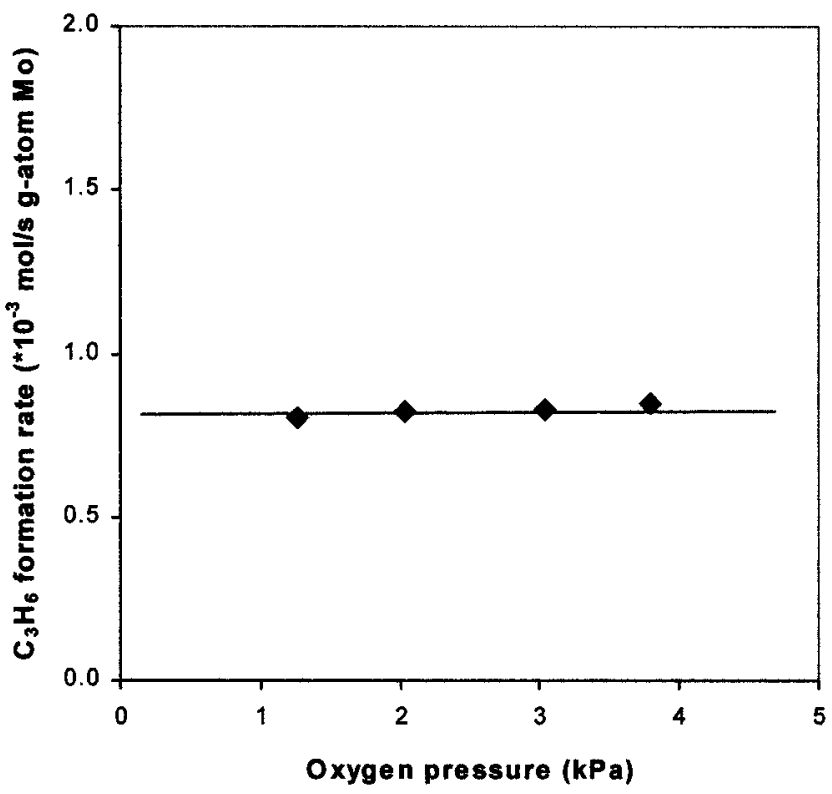

Figure 2. Effect of $\mathrm{O}_{2}$ pressure on $\mathrm{C}_{3} \mathrm{H}_{6}$ formation rate on 11 wt $\%$ $\mathrm{MoO}_{x} / \mathrm{ZrO}_{2}\left(703 \mathrm{~K}, 5.1 \mathrm{kPa} \mathrm{C} \mathrm{H}_{8}\right.$, balance $\left.\mathrm{He}\right)$.

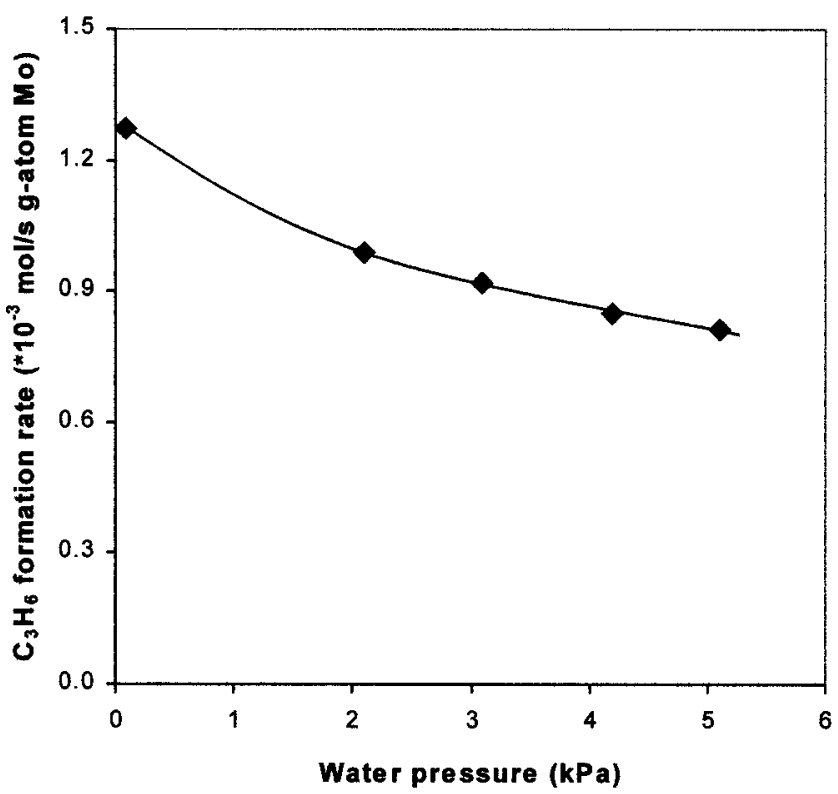

Figure 3. Effect of $\mathrm{H}_{2} \mathrm{O}$ pressure on $\mathrm{C}_{3} \mathrm{H}_{6}$ formation rate on $11 \mathrm{wt} \%$ $\mathrm{MoO}_{x} / \mathrm{ZrO}_{2}\left(703 \mathrm{~K}, 8.1 \mathrm{kPa} \mathrm{C}_{3} \mathrm{H}_{8}, 1.3 \mathrm{kPa} \mathrm{O}\right.$, balance $\left.\mathrm{He}\right)$.

using lattice oxygen atoms to abstract hydrogen atoms from $\mathrm{C}_{3} \mathrm{H}_{8}$ in an irreversible $\mathrm{C}-\mathrm{H}$ bond activation step. Propane $\mathrm{ODH}$ is envisioned to occur via the following sequence:

1. Weak associative adsorption of propane on lattice oxygen $\left(\mathrm{O}^{*}\right)$

$$
\mathrm{C}_{3} \mathrm{H}_{8}+\mathrm{O}^{*} \rightleftarrows \mathrm{C}_{3} \mathrm{H}_{8} \mathrm{O}^{*}
$$

2. $\mathrm{C}-\mathrm{H}$ cleavage via $\mathrm{H}$-abstraction from propane using a neighboring lattice oxygen

$$
\mathrm{C}_{3} \mathrm{H}_{8} \mathrm{O}^{*}+\mathrm{O}^{*} \rightarrow \mathrm{C}_{3} \mathrm{H}_{7} \mathrm{O}^{*}+\mathrm{OH}^{*}
$$

3. Desorption of propene by hydride elimination from adsorbed alkoxide species

$$
\mathrm{C}_{3} \mathrm{H}_{7} \mathrm{O} * \rightarrow \mathrm{C}_{3} \mathrm{H}_{6}+\mathrm{OH}^{*}
$$

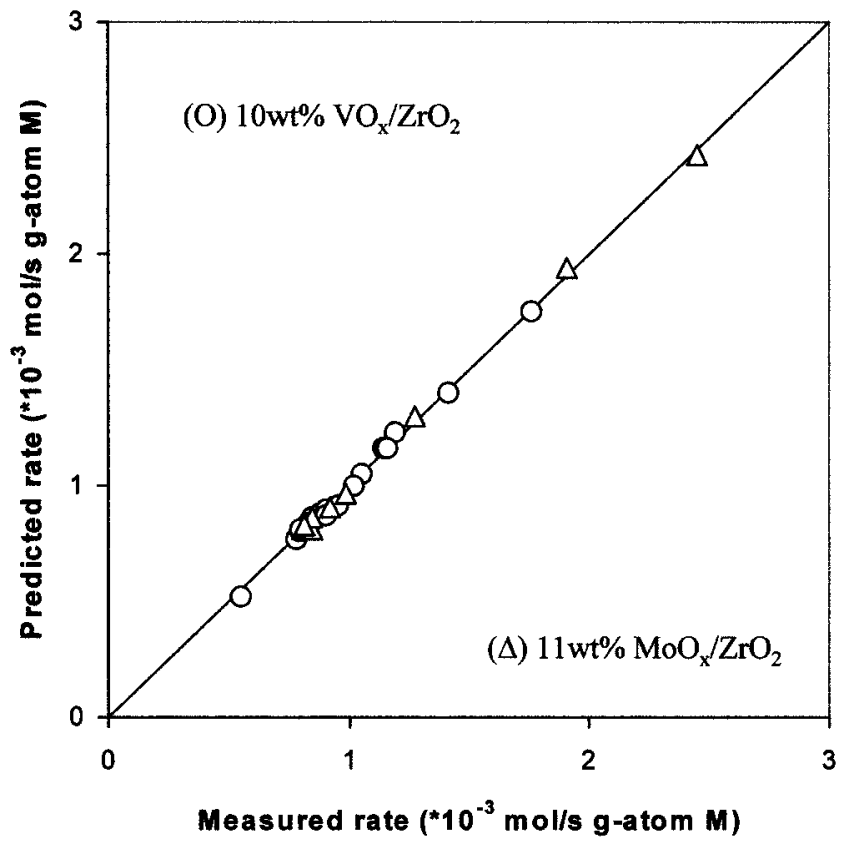

Figure 4. Comparison of predicted (from eq 1) and experimental $\mathrm{C}_{3} \mathrm{H}_{6}$ formation rates of $\mathrm{ODH}$ of propane on $10 \mathrm{wt} \% \mathrm{VO}_{x} / \mathrm{ZrO}_{2}(\mathrm{O})$ and 11 wt $\% \mathrm{MoO}_{x} / \mathrm{ZrO}_{2}(\triangle)$ catalysts.

4. Recombination of $\mathrm{OH}$ groups to form water and a reduced $\mathrm{M}$ center $(*)$

$$
\mathrm{OH}^{*}+\mathrm{OH}^{*} \rightleftarrows \mathrm{H}_{2} \mathrm{O}+\mathrm{O}^{*}+*
$$

5. Reoxidation of reduced M-centers via dissociative chemisorption of $\mathrm{O}_{2}$

$$
\mathrm{O}_{2}+*+* \rightarrow \mathrm{O}^{*}+\mathrm{O}^{*}
$$

In this scheme, $\mathrm{O}^{*}$ is a lattice oxygen atom in the $\mathrm{MO}_{x}$ overlayer (e.g., $\mathrm{M}=\mathrm{O}, \mathrm{M}-\mathrm{O}-\mathrm{M}$, or $\mathrm{M}-\mathrm{O}-\mathrm{Zr}$ ), $\mathrm{OH}^{*}$ is a hydroxyl group in $\mathrm{M}-\mathrm{O}-\mathrm{H}, \mathrm{C}_{3} \mathrm{H}_{7} \mathrm{O} *$ represents an adsorbed propoxide bonded to $\mathrm{M}\left(\mathrm{M}-\mathrm{O}-\mathrm{C}_{3} \mathrm{H}_{7}\right)$, and $*$ represents a surface vacancy associated with either one $\mathrm{Mo}^{(n-2)+}$ cation $(n$ is the highest valence of $\mathrm{M}$ ) or two $\mathrm{Mo}^{(n-1)+}$ cations in the $\mathrm{MO}_{x}$ lattice. These elementary steps, together with pseudo-steadystate assumptions for all adsorbed intermediates and quasiequilibrium assumptions for steps I and IV, lead to a rate expression of the form:

$$
\begin{array}{r}
r=k_{\mathrm{II}} K_{\mathrm{I}}\left[\mathrm{C}_{3} \mathrm{H}_{8}\right] /\left\{1+\left(K_{\mathrm{IV}}\left[\mathrm{H}_{2} \mathrm{O}\right]\right)^{0.5}\left(k_{\mathrm{II}} K_{\mathrm{I}}\left[\mathrm{C}_{3} \mathrm{H}_{8}\right] /\right.\right. \\
\left.\left.2 k_{\mathrm{V}}\left[\mathrm{O}_{2}\right]\right)^{0.25}\right\}^{2}
\end{array}
$$

where $k_{i}$ is the rate coefficient and $K_{i}$ is the equilibrium constant for step i. Figure 4 compares experimental and predicted rates (by eq 1) at various $\mathrm{C}_{3} \mathrm{H}_{8}, \mathrm{O}_{2}$, and $\mathrm{H}_{2} \mathrm{O}$ concentrations for the $\mathrm{MoO}_{x} / \mathrm{ZrO}_{2}$ and $\mathrm{VO}_{x} / \mathrm{ZrO}_{2}$ catalysts used in this study. It is evident that eq 1 describes accurately propane ODH on both catalysts at all conditions used in the study, confirming the mechanistic resemblance of ODH reactions on $\mathrm{MoO}_{x}$-based and $\mathrm{VO}_{x}$-based catalysts. The limited available kinetic data do not permit a conclusive assessment of the ODH mechanism on $\mathrm{WO}_{x} /$ $\mathrm{ZrO}_{2}$, but the chemical resemblance between Mo and $\mathrm{W}$ oxides leads us to expect that the reaction also occurs by the steps leading to eq 1.

Effects of $\mathrm{MO}_{x}$ Composition on the Rate Constants for Primary and Secondary Reactions. The effects of metal oxide 


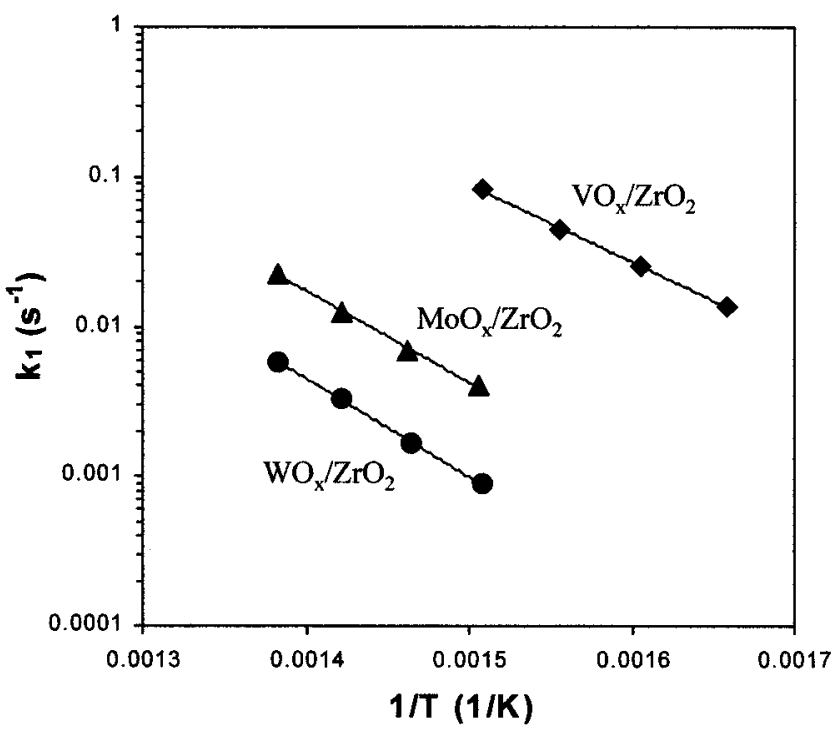

Figure 5. Temperature dependence of the propane primary dehydrogenation reaction rate constant $\left(k_{1}\right)$.

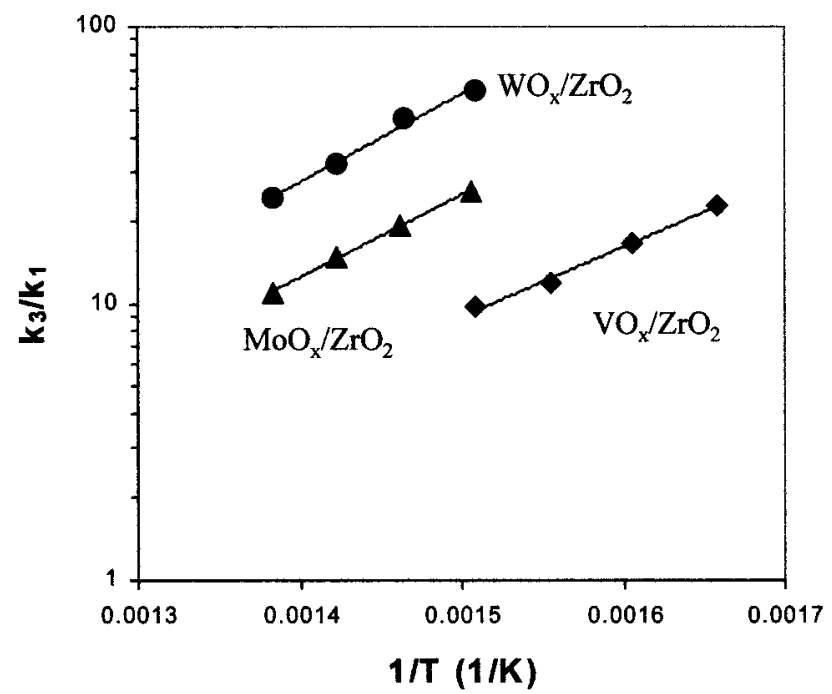

Figure 6. Temperature dependence of the reaction rate constant ratio for propene secondary combustion and propane primary dehydrogenation $\left(k_{3} / k_{1}\right)$.

composition on the apparent rate constants for reactions $1-3$ in Scheme 1 were measured at low $\mathrm{C}_{3} \mathrm{H}_{8}$ conversions in order to minimize the kinetic complexity introduced by higher $\mathrm{H}_{2} \mathrm{O}$ partial pressures. Figure 5 shows an Arrhenius plot for $k_{1}$ and Figures 6 and 7 show similar plots for $k_{3} / k_{1}$ and $k_{2} / k_{1}$, respectively. These data can be used to examine how the identity of the metal cations in $\mathrm{MO}_{x}$ influences rates and selectivities for propane $\mathrm{ODH}$ and combustion and for secondary combustion of propene.

At low $\mathrm{H}_{2} \mathrm{O}$ concentrations, the rate of propane $\mathrm{ODH}$ given by eq 1 becomes

$$
r=k_{\mathrm{II}} K_{\mathrm{I}}\left[\mathrm{C}_{3} \mathrm{H}_{8}\right]=k_{1}\left[\mathrm{C}_{3} \mathrm{H}_{8}\right]
$$

The apparent rate coefficient $k_{1}$ is, therefore, equal to $k_{\mathrm{II}} K_{\mathrm{I}}$. The equilibrium constant $\left(K_{\mathrm{I}}\right)$ can be related to the thermodynamics of propane adsorption using

$$
K_{\mathrm{I}}=\exp \left[-\left(\Delta H_{\mathrm{I}}^{\text {ads }}-T \Delta S_{\mathrm{I}}^{\text {ads }}\right) / R T\right]
$$

and the rate constant $\left(k_{\mathrm{II}}\right)$ to the thermodynamics of formation

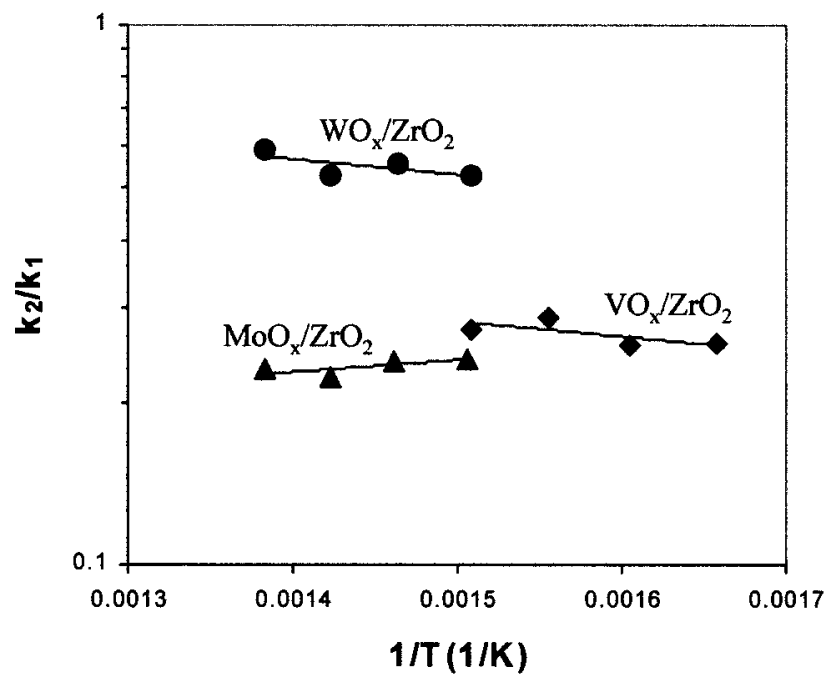

Figure 7. Temperature dependence of the reaction rate constant ratio for propane primary combustion and dehydrogenation $\left(k_{2} / k_{1}\right)$.

of the transition-state species in step $\mathrm{II}^{35}$

$$
k_{\mathrm{II}}=\left(k_{\mathrm{B}} T / h\right) \exp \left[-\left(\Delta H_{\mathrm{II}}{ }^{\mathrm{r}}-T \Delta S_{\mathrm{II}}{ }^{\mathrm{r}}\right) / R T\right]
$$

where $k_{\mathrm{B}}$ is the Boltzmann constant and $h$ is Planck's constant. $\Delta H_{\mathrm{I}}{ }^{\text {ads }}$ and $\Delta S_{\mathrm{I}}^{\text {ads }}$ are the enthalpy and entropy of propane adsorption (step I), and $\Delta H_{\mathrm{II}}{ }^{\mathrm{r}}$ and $\Delta S_{\mathrm{II}}{ }^{\mathrm{r}}$ are the enthalpy and the entropy for the formation of the transition state in step II. Combining eqs 2 and 4 leads to

$$
\begin{array}{r}
k_{1}=\left(k_{\mathrm{B}} T / h\right) \exp \left[\left(\Delta S_{\mathrm{I}}^{\text {ads }}+\Delta S_{\mathrm{II}}{ }^{\mathrm{r}}\right) / R\right] \exp \left[-\left(\Delta H_{\mathrm{I}}{ }^{\text {ads }}+\right.\right. \\
\left.\left.\Delta H_{\mathrm{II}}{ }^{\mathrm{r}}\right) / R T\right]
\end{array}
$$

If eq 5 is rewritten as

$$
k_{1}=A_{1} \exp \left(-\Delta E_{1} / R T\right)
$$

then $\Delta E_{1}$, the apparent activation energy, is given by

$$
\Delta E_{1}=\Delta H_{\mathrm{I}}^{\mathrm{ads}}+\Delta H_{\mathrm{II}}^{\mathrm{r}}
$$

and $A_{1}$, the preexponential factor, is given by

$$
A_{1}=\left(k_{\mathrm{B}} T / h\right) \exp \left[\left(\Delta S_{\mathrm{I}}^{\text {ads }}+\Delta S_{\mathrm{II}}{ }^{\mathrm{r}}\right) / R\right]
$$

Thus, the apparent activation energy for propane ODH corresponds to the sum of the adsorption enthalpy for step I and the enthalpy of formation of the transition state involved in step II. The preexponential factor reflects the sum of adsorption entropy for step I and the entropy of formation of the transition-state species in step II, because

$$
\begin{gathered}
\Delta S_{\mathrm{I}}^{\mathrm{ads}}=S\left(\mathrm{C}_{3} \mathrm{H}_{8} \mathrm{O}^{*}\right)-S\left(\mathrm{C}_{3} \mathrm{H}_{8}\right)-S(\mathrm{O} *) \\
\Delta S_{\mathrm{II}}{ }^{\mathrm{r}}=S_{\mathrm{ts}, \mathrm{II}}-S\left(\mathrm{C}_{3} \mathrm{H}_{8} \mathrm{O}^{*}\right)-S\left(\mathrm{O}^{*}\right)
\end{gathered}
$$

and therefore

$$
\Delta S_{1}=\Delta S_{\mathrm{I}}^{\mathrm{ads}}+\Delta S_{\mathrm{II}}^{\mathrm{r}}=S_{\mathrm{ts}, \mathrm{II}}-S\left(\mathrm{C}_{3} \mathrm{H}_{8}\right)-S\left(\mathrm{O}^{*}\right)-S\left(\mathrm{O}^{*}\right)
$$

$\Delta S_{1}$ reflects entropy differences between the reactant $\left(\mathrm{C}_{3} \mathrm{H}_{8}\right)$ in step I and the transition state for step II. Apparent activation energies $\left(\Delta E_{1}\right)$ and entropies $\left(\Delta S_{1}\right)$ for the primary $\mathrm{ODH}$ reaction were obtained from the data in Figure 5 and they are 
TABLE 2: Kinetic Constants for $\mathrm{MO}_{x} / \mathrm{ZrO}_{2}(\mathrm{M}=\mathrm{V}$, Mo, W) Catalysts in ODH of Propane

\begin{tabular}{llll}
\hline catalyst & $\begin{array}{c}10 \mathrm{wt} \% \\
\mathrm{VO}_{x} / \mathrm{ZrO}_{2}\end{array}$ & $\begin{array}{c}11 \mathrm{wt} \% \\
\mathrm{MoO}_{x} / \mathrm{ZrO}_{2}\end{array}$ & \multicolumn{2}{c}{$\begin{array}{c}20 \mathrm{wt} \% \\
\mathrm{WO}_{x} / \mathrm{ZrO}_{2}\end{array}$} \\
$\Delta E_{1}(\mathrm{~kJ} / \mathrm{mol})$ & 99 & 117 & 126 \\
$\Delta E_{3}(\mathrm{~kJ} / \mathrm{mol})$ & 51 & 60 & 65 \\
$\Delta E_{1}-\Delta E_{3}(\mathrm{~kJ} / \mathrm{mol})$ & 48 & 57 & 61 \\
$\Delta S_{1}(\mathrm{~J} /(\mathrm{mol} \mathrm{K}))$ & -123 & -121 & -120 \\
$\Delta S_{3}(\mathrm{~J} /(\mathrm{mol} \mathrm{K}))$ & -177 & -179 & -178
\end{tabular}

reported in Table 2 . The values of $\Delta S_{1}$ obtained are very similar on all three catalysts. Since $S\left(\mathrm{C}_{3} \mathrm{H}_{8}\right)$ is a molecular property that does not depend on the nature of the catalyst, the similar values of $\Delta S_{1}$ obtained on the three catalysts suggest that values of $S_{\mathrm{ts}, \mathrm{II}}$, and thus the structure of the activated complex, are also similar on $\mathrm{MoO}_{x}, \mathrm{VO}_{x}$, and $\mathrm{WO}_{x}$ domains. This confirms the conclusion reached from measurements of the reaction kinetics and from isotopic tracer studies that propane $\mathrm{ODH}$ proceeds via the same mechanism on $\mathrm{VO}_{x} / \mathrm{ZrO}_{2}$ and $\mathrm{MoO}_{x} / \mathrm{ZrO}_{2},{ }^{28,31}$ and possibly also on $\mathrm{WO}_{x} / \mathrm{ZrO}_{2}$. The measured activation energies $(99-126 \mathrm{~kJ} / \mathrm{mol})$ are similar to values previously reported on $\mathrm{V}_{2} \mathrm{O}_{5}-\mathrm{Nb}_{2} \mathrm{O}_{5}(72-110 \mathrm{~kJ} / \mathrm{mol}),{ }^{36}$ and they increase in the sequence

$$
\mathrm{VO}_{x} / \mathrm{ZrO}_{2}<\mathrm{MoO}_{x} / \mathrm{ZrO}_{2}<\mathrm{WO}_{x} / \mathrm{ZrO}_{2}
$$

Propane ODH rates show the opposite trend and decrease in this order; this suggests that the higher ODH rates reported on $\mathrm{VO}_{x}$-based catalysts reflect the lower activation energy for $\mathrm{C}-\mathrm{H}$ bond activation on $\mathrm{VO}_{x}$-based catalysts compared to those on catalysts based on $\mathrm{MoO}_{x}$ and $\mathrm{WO}_{x}$.

The $k_{3} / k_{1}$ ratio decreases with increasing temperature on all three catalysts (Figure 6). Assuming Arrhenius forms for $k_{1}$ and $k_{3}$, their ratio can be written as

$$
k_{3} / k_{1}=\left(A_{3} / A_{1}\right) \exp \left[\left(\Delta E_{1}-\Delta E_{3}\right) / R T\right]
$$

$\Delta E_{3}$ and $\Delta S_{3}$ values (for secondary propene combustion) were calculated from Figures 5 and 6 and they are shown in Table 2. $\Delta E_{3}$ increases in the same order as $\Delta E_{1}\left(\mathrm{VO}_{x} / \mathrm{ZrO}_{2}<\mathrm{MoO}_{x} /\right.$ $\left.\mathrm{ZrO}_{2}<\mathrm{WO}_{x} / \mathrm{ZrO}_{2}\right)$. Activation entropies for propene combustion $\left(\Delta S_{3}\right)$ over $\mathrm{VO}_{x} / \mathrm{ZrO}_{2}, \mathrm{MoO}_{x} / \mathrm{ZrO}_{2}$, and $\mathrm{WO}_{x} / \mathrm{ZrO}_{2}$ are similar (Table 2), suggesting that combustion pathways are also similar on these catalysts.

The similar site requirements for reactions 1 and 3 (suggested by the effects of $\mathrm{VO}_{x}$ structure on selectivity) ${ }^{25,26}$ and the markedly different values of $\Delta S_{3}$ and $\Delta S_{1}$ measured (Table 2) indicate that propane $\mathrm{ODH}$ (reaction 1) and propene combustion (reaction 3) pathways involve transition states with different structures. The weakest $\mathrm{C}-\mathrm{H}$ bond in alkanes and alkenes is usually cleaved in the initial step of oxidation reactions; ${ }^{38-40}$ thus, $\mathrm{C}-\mathrm{H}$ bonds at the secondary carbon and allylic $\mathrm{C}-\mathrm{H}$ bonds in propene are expected to be involved in rate-determining $\mathrm{C}-\mathrm{H}$ activation steps. This was also confirmed by the observed kinetic isotopic effects when comparing reactions of $\mathrm{CH}_{3} \mathrm{CH}_{2}$ $\mathrm{CH}_{3} / \mathrm{O}_{2}$ and $\mathrm{CH}_{3} \mathrm{CD}_{2} \mathrm{CH}_{3} / \mathrm{O}_{2}{ }^{41}$ As a result, transition states for activation of $\mathrm{C}-\mathrm{H}$ bonds in propane and propene would differ markedly, as suggested by the possible transition state structures shown in Figure 8.

The apparent activation energy for propene combustion $\left(\Delta E_{3}\right)$ is lower than for propene dehydrogenation $\left(\Delta E_{1}\right)$ on all three catalysts (Table 2). This leads to a decrease in the $k_{3} / k_{1}$ ratio (and an increase in propene yields) as temperature increases. The $\mathrm{C}-\mathrm{H}$ bond activated in propane is stronger than the allylic $\mathrm{C}-\mathrm{H}$ bond in propene; consequently, propane reaction rates are more sensitive to temperature than propene reaction rates. The
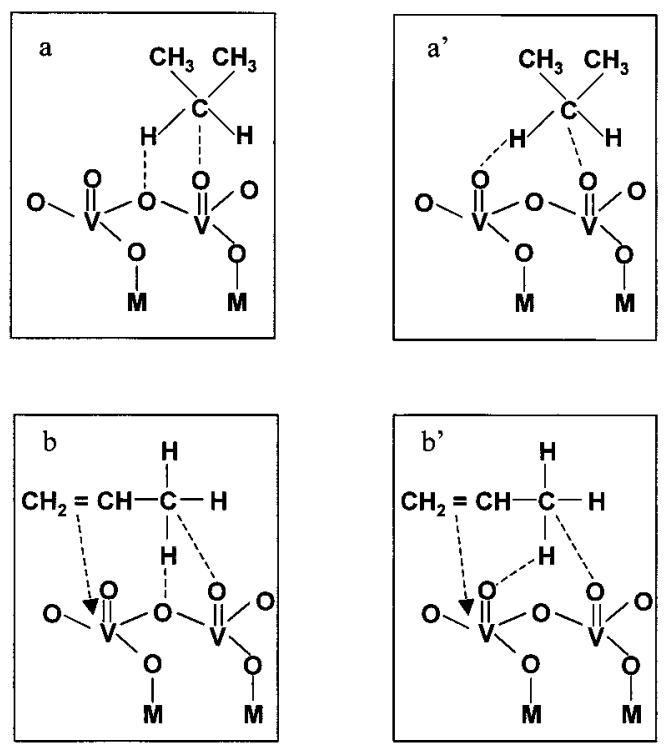

Figure 8. Speculated transition state structures of activation of propane (a and $a^{\prime}$ ) and propene ( $b$ and $\left.b^{\prime}\right)$.

difference in activation energy between the two steps $\left(\Delta E_{1}-\right.$ $\left.\Delta E_{3}\right)$ is $48-61 \mathrm{~kJ} / \mathrm{mol}$ and it increases in the sequence

$$
\begin{aligned}
\mathrm{VO}_{x} / \mathrm{ZrO}_{2}(48 \mathrm{~kJ} / \mathrm{mol})< & \mathrm{MoO}_{x} / \mathrm{ZrO}_{2}(57 \mathrm{~kJ} / \mathrm{mol})< \\
& \mathrm{WO}_{x} / \mathrm{ZrO}_{2}(61 \mathrm{~kJ} / \mathrm{mol})
\end{aligned}
$$

On selective ODH catalysts, alkene yield limitations predominantly reflect the value of the $k_{3} / k_{1}$ ratio, because $k_{2} / k_{1}$ ratios tend to be very small $(0.1-0.2) .^{25-27}$ The value of $\Delta E_{1}-\Delta E_{3}$ strongly influences $k_{3} / k_{1}$ ratios (eq 12). In what follows, we examine the specific elementary steps that influence the measured values of $k_{1}$ and $k_{3}$, as well as catalyst properties that can influence these relevant rate constants. The apparent activation energy for propane $\mathrm{ODH}$ reactions corresponds to the sum of the adsorption enthalpy in step I and the enthalpy of formation of the transition state species in step II (eq 7). A similar treatment can be used for propene activation by proposing that molecular adsorption of propene precedes activation of allylic $\mathrm{C}-\mathrm{H}$ bonds; adsorption and $\mathrm{C}-\mathrm{H}$ bond activation steps are followed by fast (and kinetically insignificant) steps required in order to complete a combustion turnover.

$$
\begin{gathered}
\mathrm{C}_{3} \mathrm{H}_{6}+\mathrm{O}^{*} \rightleftarrows \mathrm{C}_{3} \mathrm{H}_{6} \mathrm{O}^{*} \\
\mathrm{C}_{3} \mathrm{H}_{6} \mathrm{O}^{*}+\mathrm{O}^{*} \rightarrow \mathrm{C}_{3} \mathrm{H}_{5} \mathrm{O}^{*}+\mathrm{OH}^{*}
\end{gathered}
$$

This treatment leads to an apparent activation energy for propene combustion given by

$$
\Delta E_{3}=\Delta H_{\mathrm{I}^{\prime}}^{\text {ads }}+\Delta H_{\mathrm{II}^{\prime}}^{\mathrm{r}}
$$

where $\Delta H_{\mathrm{I}^{\mathrm{a}}}$ ads is the propene adsorption enthalpy and $\Delta H_{\mathrm{II}^{\mathrm{r}}}{ }^{\mathrm{r}}$ is the enthalpy of formation of the transition state for allylic $\mathrm{C}-\mathrm{H}$ bond cleavage in step $\mathrm{II}^{\prime} . \Delta E_{1}-\Delta E_{3}$ is the critical term influencing $k_{3} / k_{1}$ ratios and it is given by

$$
\begin{aligned}
\Delta E_{1}-\Delta E_{3} & =\left(\Delta H_{\mathrm{I}}^{\mathrm{ads}}-\Delta H_{\mathrm{I}^{\prime}}{ }^{\mathrm{ads}}\right)+\left(\Delta H_{\mathrm{II}}{ }^{\mathrm{r}}-\Delta H_{\mathrm{II}^{\prime}}{ }^{\mathrm{r}}\right) \\
& =\Delta\left(\Delta H^{\mathrm{ads}}\right)+\Delta\left(\Delta H^{\mathrm{r}}\right)
\end{aligned}
$$

$\Delta\left(\Delta H^{\mathrm{ads}}\right)$ represents the difference between the adsorption 
enthalpies for associative adsorption of propane and of propene on a given catalyst. $\Delta\left(\Delta H^{\mathrm{r}}\right)$ reflects the difference in the formation enthalpies for the transition states required for $\mathrm{C}-\mathrm{H}$ bond activation in propane and propene on a given catalyst. Since the $\mathrm{C}-\mathrm{H}$ bond activation steps for propane and propene appear to require similar sites, $\Delta\left(\Delta H^{\mathrm{r}}\right)$ values predominantly reflect the difference in $\mathrm{C}-\mathrm{H}$ bond dissociation enthalpies between propane and propene, while acid-base properties would influence predominantly the adsorption enthalpies of propane and propene (i.e. $\Delta\left(\Delta H^{\text {ads }}\right)$ ).

The dissociation energy for methylene $\mathrm{C}-\mathrm{H}$ bonds in propane $(401 \mathrm{~kJ} / \mathrm{mol})^{42}$ is higher than for allylic $\mathrm{C}-\mathrm{H}$ bonds in propene $(361 \mathrm{~kJ} / \mathrm{mol}){ }^{42}$ The difference in $\mathrm{C}-\mathrm{H}$ bond dissociation enthalpy between these two bonds $(40 \mathrm{~kJ} / \mathrm{mol})$ is smaller than the measured $\Delta E_{1}-\Delta E_{3}$ values $(48-61 \mathrm{~kJ} / \mathrm{mol}$; Table 2). Activation energies for propane $\mathrm{ODH}\left(\Delta E_{1}=99-126 \mathrm{~kJ} / \mathrm{mol}\right)$ and propene combustion $\left(\Delta E_{3}=51-65 \mathrm{~kJ} / \mathrm{mol}\right)$ are much smaller than the dissociation enthalpies of the bonds broken, suggesting that these $\mathrm{C}-\mathrm{H}$ bonds are cleaved via concerted interactions with lattice oxygen atoms. These concerted pathways avoid the requirement for the full dissociation energy through the concurrent exothermic formation of $\mathrm{C}-\mathrm{O}$ and $\mathrm{H}-\mathrm{O}$ bonds. Therefore, $\Delta\left(\Delta H^{\mathrm{r}}\right)$ values are not likely to reach the full $40 \mathrm{~kJ} / \mathrm{mol} \mathrm{C}-\mathrm{H}$ bond enthalpy difference between propane and propene. Yet, experimental $\Delta E_{1}-\Delta E_{3}$ values are larger than $40 \mathrm{~kJ} / \mathrm{mol}$ on all three catalysts (Table 2). We conclude that $\Delta E_{1}-\Delta E_{3}$ values must also reflect differences in adsorption enthalpy between propane and propene $\Delta\left(\Delta H^{\text {ads }}\right)$, which depend on the nature of the catalytic surface and not just on the relative bond strength in alkanes and alkenes. Adsorption processes are exothermic and stronger molecule-site interactions translate into more negative adsorption enthalpies. Propene molecules contain a $\pi$-bond, which makes them more basic than propane and which leads to stronger interactions with electron-deficient Lewis centers on oxide surfaces. As a result, propene interacts more strongly than propane with oxides containing Lewis acid centers. ${ }^{2} \mathrm{VO}_{x}, \mathrm{MoO}_{x}$, and $\mathrm{WO}_{x}$ all contain electron-deficient cations that act as Lewis acids; therefore, $\Delta\left(\Delta H^{\text {ads }}\right)$ is always positive and this term makes $\left(\Delta E_{1}-\Delta E_{3}\right)$ values larger than the $\Delta\left(\Delta H^{\mathrm{r}}\right)$ term.

Clearly, small $k_{3} / k_{1}$ ratios require small differences in adsorption enthalpies between propane and propene. $\mathrm{VO}_{x}$, $\mathrm{MoO}_{x}$, and $\mathrm{WO}_{x}$ contain electron-deficient cations that act as Lewis acid centers and $\mathrm{WO}_{x} / \mathrm{ZrO}_{2}$ has been widely studied as an acid catalyst. ${ }^{43,44}$ Lewis acid strength can be related to the electronegativity of each element in a compound and to the ratio of the square of the charge (q) to the ionic radius (r) for a given cation. In general higher electronegativity and larger $\mathrm{q}^{2} / \mathrm{r}$ values are associated with stronger Lewis acids. ${ }^{45}$ The Pauling electronegativities increase in the sequence ${ }^{46}$

$$
\mathrm{V}(1.63)<\mathrm{Mo}(2.20)<\mathrm{W}(2.36)
$$

The ionic radii of $\mathrm{V}^{5+}$ is $0.54 \AA$ and $\mathrm{Mo}^{6+}$ is $0.59 \AA$ and $\mathrm{W}^{6+}$ is $0.60 \AA$ at the same coordination number of $6 .{ }^{47}$ As a result, $q^{2} / r$ values increase in the same sequence

$$
\mathrm{V}^{5+}(46.3)<\mathrm{Mo}^{6+}(61.0) \cong \mathrm{W}^{6+}(60.0)
$$

By both criteria, the Lewis acid strength of the cations increases in the sequence $\mathrm{V}^{5+}<\mathrm{Mo}^{6+}<\mathrm{W}^{6+}$. The strength of the conjugate base (lattice oxygen atoms) decreases with increasing cation acid strength and the basicity of the lattice oxygen atoms therefore increases in the sequence

$$
\mathrm{WO}_{x} / \mathrm{ZrO}_{2}<\mathrm{MoO}_{x} / \mathrm{ZrO}_{2}<\mathrm{VO}_{x} / \mathrm{ZrO}_{2}
$$

The electron-rich $\pi$ bond causes propene to interact more strongly with electron-deficient cations (or with less basic oxygens) than propane. Therefore, $\Delta\left(\Delta H^{\text {ads }}\right)$ is always positive and it is expected to increase in the sequence

$$
\mathrm{VO}_{x} / \mathrm{ZrO}_{2}<\mathrm{MoO}_{x} / \mathrm{ZrO}_{2}<\mathrm{WO}_{x} / \mathrm{ZrO}_{2}
$$

The cleavage of allylic $\mathrm{C}-\mathrm{H}$ bonds in propene occurs away from the $\pi$ bond involved in adsorption; therefore, changes of $\Delta\left(\Delta H^{\text {ads }}\right)$ and in Lewis acid strength influence $\Delta\left(\Delta H^{\mathrm{r}}\right)$ values only weakly. For similar values of $\Delta\left(\Delta H^{\mathrm{r}}\right)$, eq 14 predicts that $\Delta E_{1}-\Delta E_{3}$ would increase as $\Delta\left(\Delta H^{\text {ads }}\right)$ and Lewis acid strength increase. The measured $\Delta E_{1}-\Delta E_{3}$ values (Table 2) indeed increase in the same sequence as the predicted Lewis acid strength of $\mathrm{V}^{5+}, \mathrm{Mo}^{6+}$, and $\mathrm{W}^{6+}$ cations.

Measured $k_{2} / k_{1}$ ratios depend only weakly on temperature on all three catalysts (Figure 7), suggesting that propane ODH and propane combustion activation energies are very similar. Both reactions use propane as the reactant and they appear to be limited by the initial activation of a methylene $\mathrm{C}-\mathrm{H}$ bond in propane. As a result, these two rates will depend on $k_{\mathrm{II}}$ and $K_{\mathrm{I}}$ values that are likely to be similar for the two reaction paths; hence, $k_{2} / k_{1}$ ratios are almost independent of temperature. The kinetic resemblance between $\mathrm{ODH}$ and combustion steps suggests that the steps that determine the fate of adsorbed alkoxide species-desorption as alkene or sequential oxidation and ultimate desorption as $\mathrm{CO}_{x}$-depend on the nature of the binding site, but they are not kinetically significant because they occur after irreversible $\mathrm{C}-\mathrm{H}$ bond activation steps. Previous studies have shown that the propane ODH and combustion reactions occur on different active sites, and that the relative abundance of these two types of binding sites is influenced by the structure of the $\mathrm{MO}_{x}$ species, as shown by the observed changes in $k_{1} / k_{2}$ ratio with changes in the surface density of $\mathrm{VO}_{x}{ }^{25,26}$ and $\mathrm{MoO}_{x}{ }^{27}$ species. The observed increase in $k_{1} / k_{2}$ values with increasing $\mathrm{VO}_{x}$ and $\mathrm{MoO}_{x}$ surface density appears to be associated with the decreasing density of $\mathrm{M}-\mathrm{O}-\mathrm{Zr}$ species, which favor strong binding of intermediate alkoxide species and the direct combustion of propane during one surface sojourn. ${ }^{25-27}$

Effects of Catalyst Structure and Chemical Properties on Catalytic ODH Reactions. In $\mathrm{ODH}$ reactions, the redox properties of oxide catalysts play an important role in determining reaction rates, ${ }^{37}$ and the relative $\mathrm{C}-\mathrm{H}$ bond energies in alkanes and alkenes strongly influence alkene yields. ${ }^{23}$ The acid-base properties of oxide catalysts, however, can also influence both reaction rates and alkene yields. ${ }^{37}$

$\mathrm{ODH}$ reaction rates reflect an apparent activation energy $\left(\Delta E_{1}\right)$ given by the sum of the enthalpy of propane adsorption $\left(\Delta H_{\mathrm{I}}{ }^{\text {ads }}\right)$ and of the $\mathrm{C}-\mathrm{H}$ bond activation energy $\left(\Delta H_{\mathrm{II}}{ }^{\mathrm{r}}\right)$ (eq 7$)$. Generally, molecular adsorption of propane is very weak and $\Delta H_{\mathrm{I}}{ }^{\text {ads }}$ values are small. As a result, $\Delta E_{1}$ values reflect predominantly $\Delta H_{\mathrm{II}}{ }^{\mathrm{r}}$ values. $\mathrm{C}-\mathrm{H}$ bond activation involves a concerted reaction with lattice oxygen atoms, which leads to $\Delta H_{\mathrm{II}}{ }^{\mathrm{r}}$ values much lower than $\mathrm{C}-\mathrm{H}$ bond dissociation energies. This step forms alkoxide and hydroxyl groups and it leads to a two-electron reduction leading to either one $\mathrm{M}^{n-2}$ or two $\mathrm{M}^{n-1}$ cations (depending on whether bridging or terminal oxygens are involved). Therefore, the value of $\Delta H_{\mathrm{II}}{ }^{\mathrm{r}}$ must also depend on the redox potential of the cations in their highest valence and on the strength of the $\mathrm{M}-\mathrm{O}-\mathrm{R}$ and $\mathrm{M}-\mathrm{O}-\mathrm{H}$ bonds. Irreversible $\mathrm{C}-\mathrm{H}$ bond activation and rapid vacancy reoxidation lead to $\mathrm{O}^{*}$ most abundant surface intermediates during $\mathrm{ODH}$ 
TABLE 3: Melting Point and Tamman Temperature of Various Metal Oxides

\begin{tabular}{ccc}
\hline metal oxides & melting point $(\mathrm{K})$ & Tamman temp $(\mathrm{K})$ \\
\hline $\mathrm{V}_{2} \mathrm{O}_{5}$ & 963 & 482 \\
$\mathrm{MoO}_{3}$ & 1068 & 534 \\
$\mathrm{Bi}_{2} \mathrm{O}_{3}$ & 1098 & 549 \\
$\mathrm{CuO}$ & 1599 & 780 \\
$\mathrm{WO}_{3}$ & 1745 & 873 \\
$\mathrm{Fe}_{2} \mathrm{O}_{3}$ & 1838 & 919 \\
$\mathrm{TiO}_{2}$ & 2128 & 1064 \\
$\mathrm{ZnO}$ & 2248 & 1124 \\
$\mathrm{NiO}$ & 2257 & 1129 \\
$\mathrm{Cr}_{2} \mathrm{O}_{3}$ & 2538 & 1269 \\
$\mathrm{ZrO}_{2}$ & 2983 & 1492
\end{tabular}

reactions. ${ }^{31}$ Then, more reducible cations will lead to smaller values of $\Delta H_{\mathrm{II}}^{\mathrm{r}}$ and $\Delta E_{1}$, to more facile reduction, and to higher $\mathrm{ODH}$ rates. The incipient cleavage of $\mathrm{C}-\mathrm{H}$ bonds in alkanes, however, also depends on the electron density (basicity) of the lattice oxygen anions that abstract the $\mathrm{H}$ atoms. ${ }^{37}$ As mentioned earlier, Lewis acidity increases in the sequence $\mathrm{V}^{5+}<\mathrm{Mo}^{6+}<$ $\mathrm{W}^{6+}$ and the electron density in the oxygen bonded to these cations increases in the sequence of $\mathrm{VO}_{x} / \mathrm{ZrO}_{2}>\mathrm{MoO}_{x} / \mathrm{ZrO}_{2}$ $>\mathrm{WO}_{x} / \mathrm{ZrO}_{2}$. Indeed, measured ODH turnover rates per $\mathrm{MO}_{x}$ on catalysts with fully exposed two-dimensional oxide domains increased in the same sequence as the corresponding basicity of the oxygen anion. The reducibility of metal centers and the basicity of the active lattice oxygen species seem to account for the sequence of catalytic activities obtained in this study $\left(\mathrm{VO}_{x} / \mathrm{ZrO}_{2}>\mathrm{MoO}_{x} / \mathrm{ZrO}_{2}>\mathrm{WO}_{x} / \mathrm{ZrO}_{2}\right.$; Figure 5).

Ultimately, very reducible oxides may become ineffective in ODH reactions because surfaces become devoid of oxygen as reduction steps become more facile than reoxidation. In such systems, $\mathrm{O}_{2}$ chemisorption rates become rate-determining and the rate actually decreases with increasing reducibility of the metal cations. This leads to a maximum rates on oxides with intermediate reducibility and to the volcano-type plots ubiquitous in heterogeneous catalysis. Similarly, intermediate basicity of lattice oxygens leads to maximum rates. As basicity increases, $\mathrm{C}-\mathrm{H}$ bond activation steps become faster, but the subsequent recombination of $\mathrm{OH}$ groups to form water (step IV) slows down and the surface becomes predominantly covered with $\mathrm{OH}$ groups. Strong basicity can also increase the stability of alkoxide species. This, in turn, would decrease the rate of desorption of the desired alkenes and increase the probability that they will instead oxidize to undesired $\mathrm{CO}_{x}$ products.

Oxygen mobility and the rate of reoxidation of oxygen vacancies can also influence $\mathrm{ODH}$ reactions. At the low water concentrations prevalent at low propane conversions, the reaction rate constants depend only on $K_{\mathrm{I}}$ and $k_{\mathrm{II}}$ and they benefit from weaker Lewis acids and more reducible cations. As water concentrations increase, the term containing water concentration in the denominator of eq 1 becomes important, the oxygen order becomes slightly positive, ${ }^{31}$ and the apparent rate constant contains a rate constant $\left(k_{\mathrm{V}}\right)$ corresponding to the reoxidation of vacancies by $\mathrm{O}_{2}$. The required dissociative chemisorption of $\mathrm{O}_{2}$ requires the migration of surface oxygen species in order to increase the probability of neighboring vacancies. In this case, lattice oxygen mobility becomes important; the Tamman temperature of metal oxides, defined as $0.5 T_{\mathrm{m}}\left(T_{\mathrm{m}}\right.$, melting point in $\mathrm{K}$ ) provides a qualitative measurement of oxygen mobility. Table 3 shows Tamman temperature of various metal oxides. ${ }^{48}$ Tamman temperatures increase in the sequence

$$
\mathrm{V}_{2} \mathrm{O}_{5}(481 \mathrm{~K})<\mathrm{MoO}_{3}(534 \mathrm{~K})<\mathrm{WO}_{3}(873 \mathrm{~K})
$$

suggesting that $\mathrm{VO}_{x}$-based catalyst would remain more active than the other oxides at the high conversions required in order to obtain high alkene yields.

Intermediate reducibility, weak Lewis acid centers, and high oxygen mobility represent the essential requirements for selective $\mathrm{ODH}$; they are consistent with the trends in ODH rates and in $k_{2} / k_{1}$ and $k_{3} / k_{1}$ ratios observed on $\mathrm{VO}_{x^{-}}, \mathrm{MoO}_{x^{-}}$, and $\mathrm{WO}_{x^{-}}$ based catalysts. They are also consistent with the widespread acceptance of $\mathrm{VO}_{x}$ and $\mathrm{MoO}_{x}$ as preferred ODH catalysts. ${ }^{1-5}$ A further decrease in the Lewis acidity of the cations in $\mathrm{VO}_{x}$ and $\mathrm{MoO}_{x}$ by modifications with oxides or supports of moderate or strong basicity (e.g., $\mathrm{MgO}, \mathrm{Cs}_{2} \mathrm{O}$ ), which increase the electron density at cation sites, should lead to less favorable adsorption of alkenes (smaller $\Delta\left(\Delta H^{\text {ads }}\right)$, and to lower $\Delta E_{1}-\Delta E_{3}$ and $k_{3} / k_{1}$ value. This is consistent with the generally higher alkene yields obtained on $\mathrm{VO}_{x}$ species supported on $\mathrm{MgO}$ compared with similar species supported on more acidic oxides (e.g., $\mathrm{Al}_{2} \mathrm{O}_{3}$ and $\mathrm{SiO}_{2}$ ) supported catalysts. ${ }^{8,9}$ Strongly basic promoters (e.g., $\mathrm{K}_{2} \mathrm{O}, \mathrm{Cs}_{2} \mathrm{O}$ ), however, also influence the redox properties of the cations and can lead to an undesired decrease the rate of ODH reactions (by increasing $\Delta H_{\mathrm{II}}^{\mathrm{r}}$ and $\left.\Delta E_{1}\right) .^{28,49,50}$

\section{Conclusions}

The oxidative dehydrogenation of propane occurs via similar elementary steps on $\mathrm{VO}_{x}$ and $\mathrm{MoO}_{x}$. The apparent activation energies for propane dehydrogenation and for propene combustion increase in the sequence $\mathrm{VO}_{x} / \mathrm{ZrO}_{2}<\mathrm{MoO}_{x} / \mathrm{ZrO}_{2}<\mathrm{WO}_{x} /$ $\mathrm{ZrO}_{2}$, while the corresponding reaction rates decrease in this same sequence. Activation energies for propane ODH are higher than for propene combustion; this leads to a decrease in $k_{3} / k_{1}$ ratios as reaction temperature increases. This difference in activation energy $(48-61 \mathrm{~kJ} / \mathrm{mol})$ is larger than the difference in bond dissociation enthalpy between the weakest $\mathrm{C}-\mathrm{H}$ bonds in propane and propene and it increases in the sequence $\mathrm{VO}_{x} /$ $\mathrm{ZrO}_{2}<\mathrm{MoO}_{x} / \mathrm{ZrO}_{2}<\mathrm{WO}_{x} / \mathrm{ZrO}_{2}$. . This suggests that the relative adsorption enthalpies of propene and propane also influence the relative reaction rates of these two molecules and that these adsorption effects depend on the Lewis acidity of the cations involved in $\pi$-bonding of alkenes on oxide surfaces. Propane ODH and propane combustion reactions show similar activation energies, suggesting that the steps involved in determining the fate of adsorbed alkoxide species (desorption vs subsequent oxidation) occur after the kinetically relevant $\mathrm{C}-\mathrm{H}$ activation steps in propane. Metal oxides having high redox properties show high catalytic activity, and less acidic metal oxides lead to smaller $\Delta E_{1}-\Delta E_{3}$ value and smaller $k_{3} /$ $k_{1}$ ratio and hence higher propene yield.

Acknowledgment. This work was supported by the Director, Office of Basic Energy Sciences, Chemical Sciences Division of the U.S. Department of Energy, under Contract DE-AC0376SF00098. The authors acknowledge useful technical discussions with Morris D. Argyle and Jonathan Male.

\section{References and Notes}

(1) Blasko, T.; López Nieto, J. M. Appl. Catal. A 1997, 157, 117.

(2) Kung, H. H. Adv. Catal. 1994, 40, 1. 38,413

(3) Albonetti, S.; Cavani, F.; Trifiro, F. Catal. Rev.-Sci. Eng. 1996.

(4) Centi, G.; Triffiro, F. Appl. Catal. A 1996, 143, 3.

(5) Mamedov, E. A.; Cortés-Corberan, V. Appl. Catal. A 1995, 127, 1.

(6) Cavani, F.; Trifiro, F. Appl. Catal. 1995, 133, 219.

(7) Busca, G. Catal. Today. 1996, 27, 457.

(8) Deo, G.; Wachs, I. E. J. Phys. Chem. 1991, 95, 5889. 
(9) Corma, A.; López Nieto, J. M.; Paredes, N.; Shen, Y.; Cao, H.; Suib, S. L. Stud. Surf. Sci. Catal. 1992, 72, 213.

(10) Michalakos, P.; Kung, M. C.; Jahan, I.; Kung, H. H. J. Catal. 1993, $140,226$.

(11) Owens, L.; Kung, H. H. J. Catal. 1994, 148, 587. 425 .

(12) Corma, A.; López Nieto, J. M.; Paredez, N. J. Catal. 1993, 144,

(13) Sananes-Schulz, M. T.; Tuel, A.; Hutchings, G. J.; Volta, J. C. J. Catal. 1997, 166, 388.

(14) Zatorski, L. W.; Centi, G.; López Nieto, J. M.; Trifiro, F.; Belussi, G.; Fattore, V. Stud. Surf. Sci. Catal. 1989, 49, 1243.

(15) Gao, X.; Ruiz, P.; Xin, Q.; Guo, X.; Delmon, B. J. Catal. 1995, $148,56$.

(16) Hanuza, J.; Jezowska-Trzebiatowska, B.; Oganowski, W. J. Mol. Catal. 1985, 29, 109.

(17) Blasko, T.; Concepción, P.; López Nieto, J. M.; Pérez-Pariente, J. J. Catal. 1995, 152, 1.

(18) Meunier, F. C.; Yasmeen, A.; Ross, J. R. H. Catal. Today 1997, 37,33 229.

(19) Cadus, L. E.; Gomez, M. F.; Abello, M. C. Catal. Lett. 1997, 43,

(20) Yoon, Y. S.; Fujikawa, N.; Ueda, W.; Moro-oka, Y.; Lee, K. W. Catal. Today 1995, 24, 327.

(21) Yoon, Y. S.; Ueda, W.; Moro-oka, Y. Top. Catal. 1996, 3, 256

(22) Lee, K. H.; Yoon, Y. S.; Ueda, W.; Moro-oka, Y. Catal. Lett. 1997 $46,267$.

(23) Cassidy, F. E.; ; Hodnett, B. K. CATTECH 1998, 2, 173.

(24) Zanthoff, H. W.; Lahmer, M.; Baerns, M.; Klemm, E.; Seitz, M.; Emig, G. J. Catal. 1997, 172, 203.

(25) Khodakov, A.; Yang, J.; Su, S.; Iglesia, E.; Bell, A. T. J. Catal. 1998, 177,343 .

(26) Khodakov, A.; Olthof, B.; Bell, A. T.; Iglesia, E. J. Catal. 1999, $181,205$.

(27) Chen, K.; Xie, S.; Iglesia, E.; Bell, A. T. J. Catal., in press.

(28) Prinetto, F.; Cerrato, G.; Ghiotti, G.; Chiorino, A. J. Phys. Chem. $1995,99,5556$.

(29) Barton, D. G.; Soled, S. L.; Meitzner, G. D.; Fuentes, G. A.; Iglesia, E. J. Catal. 1999, 181, 57.
(30) Barton, D. G.; Shtein, M.; Wilon, R. D.; Soled, S. L.; Iglesia, E. J. Phys. Chem. B 1999, 103, 630.

(31) Chen, K.; Khodakov, A.; Yang, J.; Bell, A. T.; Iglesia, E. J. Catal. 1999, $186,325$.

(32) Michaels, J. N.; Stern, D. L.; Grasselli, R. K. Catal. Lett. 1996 $42,139$.

(33) Stern, D. L.; Grasselli, R. K. J. Catal. 1997, 167, 560.

(34) Oyama, S. T.; Middlebrook, A. M.; Somorjai, G. A. J. Phys. Chem. $1990,94,5029$.

(35) Boudart, M.; Djéga-Mariadassou. Kinetics of Heterogeneous Catalytic Reactions; Princeton University Press: Princeton, NJ, 1984.

(36) Smits, R. H. H.; Seshan, K.; Leemreize, H.; Ross, J. R. H. Catal. Today 1993, 16, 513 .

(37) Banares, M. A. Catal. Today 1999, 51, 319.

(38) Pepera, M. A.; Callahan, J. L.; Desmond, M. J.; Milberger, E. C.; Blum, P. R.; Bremer, N. J. J. Am. Chem. Soc. 1985, 107, 4883.

(39) Adams, C. R.; Jennings, T. J. J. Catal. 1963, 2, 63.

(40) Adams, C. R.; Jennings, T. J. J. Catal. 1964, 3, 549.

(41) Chen, K.; Iglesia, E.; Bell, A. T. J. Catal., submitted for publication.

(42) CRC Handbook of Chemistry and Physics, 71st ed.; CRC Press: Boca Raton, FL, 1990; pp 9-95.

(43) Hino, M.; Arata, K. J. Chem. Soc., Chem. Commun. 1988, 1259.

(44) Iglesia, E.; Barton, D. G.; Soled, S. L.; Miseo, S.; Baumgartner, J. E.; Gates, W. E.; Fuentes, G. A.; Meitzner, G. D. Stud. Surf. Sci. Catal. 1996, 101, 533.

(45) Douglas, B. E.; McDaniel, D. H.; Alexander, J. J. Concepts and Models of Inorganic Chemistry, 3rd ed.; John Wiley \& Sons: New York, 1994; p 309.

(46) Porterfield, W. W. Inorganic Chemistry: a unified approach, 2nd ed.; Academic Press Inc.: New York, 1993; p 46.

(47) CRC Handbook of Chemistry and Physics, 79th ed.; CRC Press: Boca Raton, FL, 1998; pp 12-15.

(48) CRC Handbook of Chemistry and Physics, 69th ed.; CRC Press: Boca Raton, FL, 1988.

(49) Qwens, L.; Kung, H. H. J. Catal. 1994, 148, 587.

(50) Abello, M. C.; Gomez, M. F.; Cadus, L. E. Catal. Lett. 1998, 53, 185 